\title{
SEROPREVALENCE FOR HEPATITIS E VIRUS (HEV) INFECTION AMONG VOLUNTEER BLOOD DONORS OF THE REGIONAL BLOOD BANK OF LONDRINA, STATE OF PARANÁ, BRAZIL
}

\author{
André Luiz BORTOLIERO(1), Ana Maria BONAMETTI(1), Helena Kaminami MORIMOTO(2),Tiemi MATSUO(3) \& Edna Maria Vissoci REICHE(2)
}

\begin{abstract}
SUMMARY
A cross-sectional study was carried out among 996 volunteer blood donors enrolled from May 1999 to December 1999 to determine the seroprevalence of hepatitis E virus (HEV) infection among volunteer blood donors of the Regional Blood Bank of Londrina, State of Paraná, Brazil, and to evaluate whether the rate of seroprevalence of IgG anti-HEV antibodies is associated with sociodemographic variables and with seropositivity for hepatitis A virus (HAV) infection. All participants answered the questionnaire regarding the sociodemographic characterisitcs. Serum samples were tested for IgG antibodies to HEV (anti-HEV) by an enzyme linked immunoassay (ELISA). All serum samples positive for anti-HEV IgG and 237 serum samples negative for anti-HEV were also assayed for IgG anti-HAV antibodies by ELISA. Anti-HEV IgG was confirmed in 23/996 samples, resulting in a seroprevalence of $2.3 \%$ for HEV infection, similar to previous results obtained in developed countries. No significant association was found between the presence of anti-HEV IgG antibodies and the sociodemographic variables including gender, age, educational level, rural or urban areas, source of water, and sewer system $(\mathrm{p}>0.05)$. Also, no association with seropositivity for anti-HAV IgG antibodies was observed ( $p>0.05$ ). Although this study revealed a low seroprevalence of HEV infection in the population evaluated, the results showed that this virus is circulating among the population from Londrina, South Brazil, and point out the need of further studies to define the clinical and epidemiological importance of HEV infection and to identify additional risk factors involved in the epidemiology and pathogenesis of this infection in this population.
\end{abstract}

KEYWORDS: Hepatitis E virus; Hepatitis A virus; Epidemiology; Seropositivity; Blood donors.

\section{INTRODUCTION}

Epidemic jaundice has been recognized from the time of Hippocrates over 2000 years ago. However, it was only between 1965 and 1990 that the various human hepatitis viruses, their syndromes and their role in hepatic oncogenesis were determined, leading to the expansion of their nomenclature from A to E. It has been estimated that between four and $19 \%$ of patients with sporadic, communityacquired acute hepatitis have no detectable viral agent ${ }^{22}$.

Hepatitis E virus (HEV) is considered a major etiological agent of enterically transmitted viral hepatitis in several developing countries ${ }^{25}$. The infection has been shown to occur in both epidemic and sporadic forms and to be primarily associated with ingestion of fecally contamined drinking water ${ }^{31}$.

HEV infection is quite common in some world areas such as India, Africa and Southeast Asia, where it can represent the main cause of acute hepatitis ${ }^{27}$. In India, this infection is the main cause of sporadic cases of non-A, non-B and non-C hepatitis ${ }^{18}$. Outbreaks of HEV infection have been reported from Central Asia, Southeast Asia, the
Middle East, Northern Africa, Sub-Saharan Africa, and Mexico ${ }^{31}$. In the Xinjiang area of China, 119,280 cases of HEV infection were notified in the epidemic of 1986 to $1988^{19}$.

In addition, epidemiological investigation in non-endemic areas has shown a low, but constant presence of anti-HEV antibodies (about $1.2 \%$ ) in normal human populations ${ }^{27,31}$. In Brazil, outbreaks of hepatitis E have never been reported, although some authors have demonstrated the evidence of anti-HEV antibodies in some population groups ${ }^{12,24,27,31}$. The seroprevalence of anti-HEV IgG among normal Brazilian populations was reviewed ${ }^{8}$ and reported a positivity of $6.1 \%$ among gold miners, $3.3 \%$ in the general population, 2.0-7.5\% among blood donors, $1.0 \%$ among pregnant women, and $4.5 \%$ in children, with no difference among regions. The review also showed that the prevalence of anti-HEV varies widely in populations considered to be at risk. Among patients with acute non-A, non-B, non-C hepatitis, the prevalence was $2.1 \%$ in the Southeast, $29 \%$ in the Northeast, $10.6 \%$ among relative of acute non- $\mathrm{A}$, non-B, non-C hepatitis patients in the Amazon basin, 12\% among acute sporadic non-A non-B hepatitis patients in the Northeast, 25 to $38 \%$ among patients co-infected with acute hepatitis $\mathrm{A}$ in the Northeast, 14 to $18 \%$ among prostitutes and 


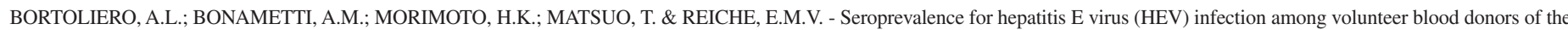
Regional Blood Bank of Londrina, State of Paraná, Brazil. Rev. Inst. Med. trop. S. Paulo, 48(2):87-92, 2006.

women considered at risk for human immunodeficiency virus type 1 (HIV-1) in the Southeast, and 12\% among intravenous drug users in the Southeast ${ }^{8}$. In the State of Paraná, South Brazil, no studies of the HEV infection have been reported.

HEV infection usually presents an acute and benign clinical course and does not provoke chronic infection. However, among all the responsible hepatitis viruses, $\mathrm{HEV}$ is associated with the largest number of fulminant hepatitis cases $(3.0 \%)$ in the general population, and up to $20 \%$ in pregnant women ${ }^{7}$.

Hepatitis A virus (HAV) is an extremely stable virus which is spread by the fecal-oral route, either directly from person to person or by contamined food or water, with the prevalence being closely correlated with the degree of environmental sanitation and the prevailing socioeconomic and hygienic conditions ${ }^{33}$. Considering that the HEV and HAV infections share the same transmission routes, it is possible that the local seroprevalence of both infections may also be similar. However, few studies have examined the epidemiology of the association between HEV and HAV infections.

The aim of this study was to determine the seroprevalence of HEV infection among volunteer blood donors of the Regional Blood Bank of Londrina, State of Paraná, Brazil, and to evaluate whether the rate of seroprevalence of anti-HEV IgG antibodies is associated with the sociodemographic characterisitcs and the seropositivity for HAV infection. These data can contribute to define the epidemiological importance of the HEV infection in this district and to elaborate rational clinical and epidemiological strategies in the investigation of cases classified as non-A, non-B, and non-C hepatitis.

\section{MATERIALS AND METHODS}

A cross-sectional study was carried out to determine the seroprevalence of HEV infection among volunteer blood donors of the Blood Bank of the Universitary Hospital, Londrina, State of Paraná, South Brazil. The protocol was approved by the institutional Research Ethics Committee of Londrina State University. The individuals were invited to participate and informed in detail about the research, and voluntary written consent was obtained from the subjects enrolled.

Study population: The convenience sample consisted of individuals consecutively recruited during the period from May 1999 to December 1999. For the population of 250,000 adults aged 18 to 60 years living in district of Londrina, with an estimated prevalence of seropositivity for HEV infection of 0.025 (with an error margin of 0.01 ), the calculated sample size was of 933 individuals, with a confidence interval (CI) of $95 \%$. In order to decrease the margin of error, 996 blood donors were evaluated. A questionnaire was applied to the participants to obtain information about sociodemographic data including gender, age, educational level, place of residence (rural or urban area), source of water, and the sanitary conditions of their homes (sewer or pit), in order to evaluate possible risk factors for HEV infection. On the basis of the standard clinical screening of the blood donors, all individuals enrolled in this study were also questioned about a past clinical history of symptomatic hepatitis.

The results obtained for the blood donors with positive anti-HEV
IgG were compared with those obtained for blood donors with negative anti-HEV IgG.

Serological assays for anti-HEV IgG and anti-HAV IgG: All serum samples were stored at $-20{ }^{\circ} \mathrm{C}$ until used. Serum samples were tested for specific anti-HEV IgG antibodies by enzyme linked immunosorbent assay (ELISA), according to the method described elsewhere ${ }^{32}$ using commercially available reagents (HEV EIA, ABBOTT Laboratories, IL, USA). According to the manufacturer, this assay presents $98.5 \%$ sensitivity and $99.5 \%$ specificity. The results were scored as positive or negative according to standard procedures recommended by the manufacturers. The individuals were considered to be seropositive when they showed two repeated positive reactions. Positive and negative controls were included in all the ELISA microplates assayed. All serum samples from blood donors positive for anti-HEV IgG and 237 samples from blood donors negative for anti-HEV IgG were also assayed for anti-HAV IgG antibodies by ELISA, as described elsewhere ${ }^{11}$, using commercially available products (ABBOTT Laboratories, HAV EIA). According to the manufacturer, the assay presents $99.0 \%$ sensitivity and $99.5 \%$ specificity.

Statistical analysis: A database was set up using the EPI INFO software version $6.04 \mathrm{~d}^{10}$. Descriptive statistical analysis was used to calculate the mean, median, standard deviation (SD), and percentage of the sociodemographic variables of the blood donors, and $95 \%$ confidence intervals $(95 \% \mathrm{CI})$ of the proportion of seropositivity for anti-HEV IgG and anti-HAV IgG antibodies and the variables evaluated. The statistical analysis was performed using the Chi-square $\left(x^{2}\right)$ and Exact Fisher tests. The level of significance adopted for all tests was $5 \%(\mathrm{p}<0.05)$.

\section{RESULTS}

The age of the volunteer blood donors ranged from 18 to 60 years (mean: $29.9 \pm 9.8$ years; median: 26.9 years) and $605(60.7 \%)$ were males. Table 1 shows that 23 blood donors showed positive anti-HEV $\mathrm{IgG}$ antibodies, corresponding to an overall seroprevalence rate of $2.3 \%$ $(95 \% \mathrm{CI}=1.5-3.5)$. The sociodemographic characteristics of the blood donors enrolled according to seropositivity for anti-HEV IgG are shown in Table 2. No association was observed $(\mathrm{p}>0.05)$ between seropositivity and the variables evaluated including gender, age $(\leq 35$ years old and $>35$ years old), educational level (incomplete elementary school and $\geq$ elementary school), origin (urban or rural area), source of water (public or other) and sewer (public service or pit). Most subjects lived under adequate sanitary housing conditions in view of the high

\section{Table 1}

Distribution of the results of anti-hepatitis virus E antibodies (anti-HEV) IgG in serum samples from volunteer blood donors of the Regional Blood Bank of Londrina, Paraná, Brazil

\begin{tabular}{lccc}
\hline ANTI-HEV IgG $*$ & Number & $\%$ & $\mathrm{CI}^{\dagger}(95 \%)$ \\
\hline Positive & 23 & 2.3 & $1.5-3.5$ \\
Negative & 973 & 97.7 & $96.5-98.5$ \\
Total & 996 & 100.0 & \\
\hline
\end{tabular}

* Anti-hepatitis virus E IgG antibodies evaluated by enzyme immunoassay (ELISA); ${ }^{\dagger}$ : confidence interval. 
rate of presence of a sewage system $(73.2 \%)$ and public water $(98.6 \%)$. All the $23(100.0 \%)$ subjects with positive results for anti-HEV IgG and $959(98.6 \%)$ with negative results had public piped water available. Therefore, there was no statistically significant difference in anti-HEV prevalence when the presence of a sewage system and the source of water were taken into consideration.

The results obtained from the 23 blood donors with positive antiHEV IgG were compared with those obtained from 237 blood donors with negative anti-HEV IgG. Among the 260 serum samples assayed for anti-HAV IgG, 211 were positive for anti-HAV IgG, corresponding to a seropositivity of $81.1 \%$. Among the positive samples for antiHEV IgG, 19 (82.6\%) were also positive for anti-HAV IgG. Regarding the samples that were negative for anti-HEV IgG, $192(81.0 \%)$ were also positive for anti-HEV IgG. No association between the two rates of seropositivity (anti-HEV and anti- HAV) was observed ( $\mathrm{p}=1,000)$, as shown in Table 3.

\section{DISCUSSION}

Viral hepatitis is considered to be a worldwide public health problem, representing a significant cause of morbidity and mortality. On most occasions, the etiologic agent of the infection is not defined, generating problems in the handling of those cases and in the decision about the most adequate prophylactic measures.

The areas of the world with a high incidence of HEV infection are mainly developing countries, mainly in Asia and in Africa. In Brazil, different patterns of hepatitis virus distribution are found throughout the country. Outbreaks of HEV infection have not yet been described. However, the possibility of the occurrence of such outbreaks exists since in our country there are great social differences and sanitary conditions are quite precarious in many areas. Besides, the disease surveillance is deficient in the country as a whole, with the consequent serious problem of undernotification of cases.

Table 2

Sociodemographic characteristics of 996 volunteer blood donors of the Regional Blood Bank of Londrina, Paraná, Brazil, distributed according to seropositivity for anti-hepatitis virus E (anti-HEV IgG) antibodies

\begin{tabular}{|c|c|c|c|c|}
\hline Characteristic & $\begin{array}{c}\text { Anti-HEV positive } \\
\text { n }(\%)\end{array}$ & $\begin{array}{c}\text { Anti-HEV negative } \\
\text { n }(\%)\end{array}$ & $\begin{array}{l}\text { Total } \\
\mathrm{n}(\%)\end{array}$ & $\mathrm{p}$ value \\
\hline \multicolumn{5}{|l|}{ Gender } \\
\hline Male & $15(65.2)$ & $590(60.6)$ & $605(60.7)$ & \multirow[t]{2}{*}{$0.8190 * \mathrm{NS}$} \\
\hline Female & $8(34.8)$ & $383(39.4)$ & $391(39.3)$ & \\
\hline \multicolumn{5}{|l|}{ Age (years) } \\
\hline$\leq 35$ & $17(73.9)$ & $692(71.1)$ & $709(71.2)$ & \multirow{2}{*}{$0.9526 * \mathrm{NS}$} \\
\hline$>35$ & $6(26.1)$ & $281(28.9)$ & $287(28.8)$ & \\
\hline \multicolumn{5}{|l|}{ Place of residence } \\
\hline Rural area & $2(8.7)$ & $58(6.0)$ & $60(6.0)$ & \multirow[t]{2}{*}{$0.6442^{\dagger} \mathrm{NS}$} \\
\hline Urban area & $21(91.3)$ & $915(94.0)$ & $936(94.0)$ & \\
\hline \multicolumn{5}{|l|}{ Education } \\
\hline Elementary school & $5(21.7)$ & $175(18.0)$ & $180(18.1)$ & \multirow[t]{2}{*}{$0.5886^{\dagger} \mathrm{NS}$} \\
\hline$\geq$ Elementary school & $18(78.3)$ & $798(82.0)$ & $816(81.9)$ & \\
\hline \multicolumn{5}{|l|}{ Source of water } \\
\hline Public & $23(100.0)$ & 959 (98.6) & $982(98.6)$ & \multirow[t]{2}{*}{$1.000^{\dagger} \mathrm{NS}$} \\
\hline Other (mine, shaft) & $0(0.0)$ & $14(1.4)$ & $14(1.4)$ & \\
\hline \multicolumn{5}{|l|}{ Sanitary conditions } \\
\hline Sewer & $14(60.9)$ & $715(73.5)$ & $729(73.2)$ & \multirow[t]{2}{*}{$0.2660 * \mathrm{NS}$} \\
\hline Pit (closed and open) & $9(39.1)$ & $258(26.5)$ & $267(26.8)$ & \\
\hline
\end{tabular}

* Chi-square test $\left(x^{2}\right) ;{ }^{\dagger}$ Exact Fisher Test; n: number of samples; NS: not significant.

Table 3

Seropositivity for anti-hepatitis A virus (anti-HAV) IgG antibodies obtained for volunteer blood donors of the Regional Blood Center of Londrina, Paraná, Brazil, distributed according to the seropositivity for anti-hepatitis E virus (anti-HEV) IgG antibodies

\begin{tabular}{|c|c|c|c|c|}
\hline Serologic result & Anti-HEV*Positive n $(\%)$ & Anti-HEV*Negative n (\%) & Total n $(\%)$ & $\mathrm{CI}^{\ddagger}(95 \%)$ \\
\hline Anti-HAV ${ }^{\dagger}$ positive & $19(82.6)$ & $192(81.0)$ & $211(81.1)$ & $75.75-85.61$ \\
\hline Anti-HAV $^{\dagger}$ negative & $4(17.4)$ & $45(19.0)$ & $49(18.8)$ & $14.39-24.25$ \\
\hline Total & $23(100.0)$ & $237(100.0)$ & $260(100.0)$ & \\
\hline
\end{tabular}

*: Anti-hepatitis E virus IgG antibodies evaluated by enzyme immunoassay (ELISA); ${ }^{\dagger}$ : Anti-hepatitis A virus IgG antibodies evaluated by enzyme immunoassay (ELISA); Exact Fisher Test: $\mathrm{p}=1.000$ (not significant); ${ }^{\star} \mathrm{CI}$ : confidence interval. 


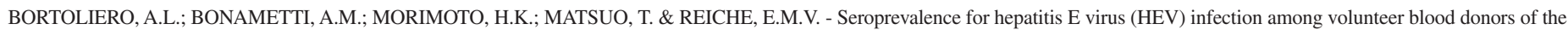
Regional Blood Bank of Londrina, State of Paraná, Brazil. Rev. Inst. Med. trop. S. Paulo, 48(2):87-92, 2006.

According to the Municipal Health System, in the district of Londrina, State of Paraná, in the year of 1999, it was not possible to identify the etiologic agent in $6 \%$ of the total of cases of viral hepatitis and those cases were classified as non-A, non-B, and non-C hepatitis infections (personal communication). On this basis, it is possible that some of those cases might have been HEV infection.

The $2.3 \%$ seroprevalence of anti-HEV IgG obtained among volunteer blood donors residing in the district of Londrina enrolled in this study is similar to that reported in other recently reviewed Brazilian studies $^{8}$. In the city of São Paulo, State of São Paulo, a previous investigation detected a seroprevalence of $1.68 \%$ for anti-HEV IgG antibodies in the general population ${ }^{12}$. In another study carried out in Campinas, State of São Paulo, the seroprevalence was 3.0\% among blood donors from that municipal district ${ }^{13}$. In Salvador (State of Bahia), the seroprevalence of anti-HEV IgG antibodies among blood donors was $2.0 \%{ }^{24}$. In Rio de Janeiro (State of Rio de Janeiro), a retrospective study conducted on selected populations revealed a $4.3 \%$ of prevalence of anti-HEV IgG among the different groups and among blood donors ${ }^{31}$. In a study carried out in riverine communities from the Western Region of the Brazilian Amazon Basin, the overall prevalence observed (4.0\%) was considered to be $l^{25}$.

As mentioned previously, the main route of transmission of $\mathrm{HEV}$ infection is the fecal-oral one, which is also the route of transmission of HAV infection, whose prevalence is associated with the quality of the individuals' life including housing, drinking water, and sewer service $^{5}$. HAV infection is highly prevalent in Brazil, as demonstrated in a study carried out in the city of São Paulo, State of São Paulo, on individuals ranging in age from 16 to 30 years, in which the prevalence of anti-HAV was $91.9 \%$ among individuals of middle socioeconomic condition and $100 \%$ among those of low socioeconomic condition ${ }^{23}$.

Regarding the similarity of the transmission mechanisms, there is a trend to evaluate the association between these two infections (HAV and HEV infections). A study carried out in Israel on hemophiliac patients detected a strong association between the viruses ${ }^{6}$. In Brazil, the same association was found in a study carried out in Salvador, State of Bahia, and the authors concluded that similarities exist between the epidemiology of the two infections, and that individuals exposed to HAV have a higher probability to be also exposed to $\mathrm{HEV}^{24}$.

In the present study, no association was found between these two infections, a result similar to that reported in a study that evaluated the prevalence of these viruses in the general population of the city of São Paulo, State of São Paulo ${ }^{12}$. Also, no association was found in the urban population of Burundi, Africa, and the authors concluded that, although the two viruses are transmitted by the fecal-oral route, the epidemic models of the two infections are different ${ }^{3}$. HEV infection has a few distinct epidemiological features that differentiate it from HAV infection. Unlike HAV infection, HEV infection appears to affect mainly young adults, which is unusual for a virus transmitted via the fecaloral route. Also unusual is that secondary cases of HEV infection are much less frequent than HAV infection, and finally a major difference is the high mortality rate observed among pregnant women infected with $\mathrm{HEV}^{31}$.

In California (USA), a group of candidates to blood donors was evaluated and the results did not show an association between those infections and the authors concluded that, possibly, different patterns of transmission of the two viruses may exist and the risk factors for $\mathrm{HEV}$ infection in the sporadic cases that occur in non-endemic areas have not been defined ${ }^{20}$.

Similarly, in this study, since the association of the type of water consumed, including the use of untreated water, with the soroprevalence of IgG anti-HEV antibodies was not demonstrated, other possible transmission routes should be suggested.

HEV infection, unlike HAV infection, presents a very low rate of inter-human transmission, as demonstrated by several authors $1,3,15,26,28,30$. According to these authors, this route of transmission of HEV infection should not be the only one responsible for the sporadic cases that occur in non-endemic areas. Other transmission mechanisms, not yet clarified, may play an important role in the epidemiology of HEV infection in these areas.

According to some authors, HEV infection could be classified as a zoonosis because some animals may act as reservoirs of the virus, a fact justifying the circulation of the virus in non-endemic areas $4,9,14,16,17,26$. Occasionally, HEV may infect humans through direct contact with domestic or farm animals or with contaminated water supplies ${ }^{25}$.

The analysis of the genome of the HEV isolated from swine and from individuals with HEV infection suggests that these animals can serve as a reservoir of the virus ${ }^{21}$. The existence of cross-infection with HEV between humans and swine is a possibility that cannot be ruled out ${ }^{36}$. The high prevalence of HEV antibodies among apparently healthy humans $(20.0 \%)$ and farm pigs $(72.0 \%)$ in Bali, Indonesia, whose population is mostly Hindu and has a habit of consuming pork, indicates that HEV infection may occur as a zoonosis ${ }^{35}$.

In a study, related by authors as the first report that showed evidences of HEV circulation in Brazilian animal species and pig handlers, was detected the soroprevalences of HEV infection in cows $(1.42 \%)$, dogs $(6.97 \%)$, chickens $(20 \%)$, swines $(24.3 \%)$ and rodents $(50.0 \%)$, as well in pig handlers $(6.3 \%)^{34}$. The recognition of swine $\mathrm{HEV}$ infection in pigs in many countries of the world led these authors to investigate a larger sample of pigs of same Brazilian region that demonstrated a total seroprevalence of $63.6 \%$. However, as the seroprevalence reached $97.3 \%$ of animals older than 25 weeks, the authors concluded that swine HEV infection seems to be almost universal within this Brazilian pig population ${ }^{34}$.

The true participation of the animals in the transmission of HEV is still unclear, with many points that still require elucidation. Similarly, the true meaning of the seroprevalence of the anti-HEV IgG antibodies detected in the present study it is still to be defined.

Taken together, although showing a low prevalence of HEV infection among blood donors, the results obtained in the present study demonstrate that HEV circulates in the district of Londrina. However, further studies are necessary to define the clinical and epidemiologic importance of the HEV infection in this area and to identify additional risk factors involved in the epidemiology and pathogenesis of HEV infection. The results obtained open the possibility of other routes of 


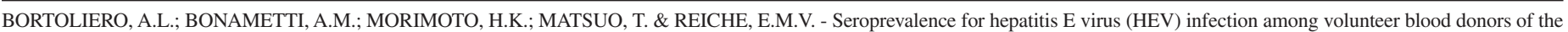
Regional Blood Bank of Londrina, State of Paraná, Brazil. Rev. Inst. Med. trop. S. Paulo, 48(2):87-92, 2006.

spreading different from that previously recognized ones such as fecaloral contamination, mainly the possible participation of animals in the transmission of HEV.

\section{RESUMO}

\section{Soroprevalência da infecção pelo virus da hepatite E (VHE) em candidatos a doadores de sangue voluntários do Hemocentro Regional de Londrina, Londrina, Estado do Paraná, Brasil}

Os objetivos do estudo foram determinar a soroprevalência da infecção pelo vírus da hepatite $\mathrm{E}$ (VHE) em candidatos a doadores de sangue voluntários do Hemocentro Regional de Londrina, Paraná, e avaliar se essa soroprevalência está associada com variáveis sociodemográficas e com o índice de soropositividade para hepatite por vírus A (VHA). Foi realizado estudo transversal para determinar a taxa de soroprevalência da infecção pelo VHE em 996 candidatos a doadores de sangue. Todos os participantes responderam um questionário sobre características sociodemográficas. A pesquisa de anticorpos específicos IgG anti-VHE foi realizada por método de enzimaimunoensaio (ELISA). Todas as amostras soropositivas para IgG anti-VHE e 237 amostras soronegativas para IgG anti-VHE foram submetidas também à pesquisa de IgG anti-VHA por ELISA. Entre as 996 amostras de soro analisadas, anticorpos IgG anti-VHE foram detectados em 23 amostras, resultando em uma soroprevalência de 2,3\% (IC 95\%: 1,5 $3,5)$, semelhante aos resultados de estudos realizados em países desenvolvidos. Não houve associação entre o índice de soropositividade de IgG anti-VHE e as variáveis sociodemográficas (sexo, idade, escolaridade, procedência, fonte de água e origem dos dejetos); também não se detectou associação entre soropositividade para IgG anti-VHE com soropositividade para IgG anti-VHA. Os resultados obtidos sugerem que, embora tenha se observado uma baixa prevalência da infecção pelo VHE na população analisada, verificou-se que existe circulação do VHE no município de Londrina e que estudos posteriores são necessários para definir a importância clínica e epidemiológica da infecção pelo VHE nesse município bem como identificar outros possíveis fatores de risco envolvidos na epidemiologia da infecção pelo VHE.

\section{REFERENCES}

1. AGGARWAL, R. \& NAIK, S.R. - Hepatitis E: intrafamilial transmission versus waterborne spread. J. Hepat., 21: 718-723, 1994.

2. ARANKALLE, V.A; CHADHA, M.S; MEHENDALE, S.M. \& TUNGATKAR, S.P. Epidemic hepatitis E: serological evidence for lack of intrafamilial spread. Indian J. Gastroent., 19: 24-28, 2000.

3. AUBRY, P.; NIEL, L.; NIYONGABO, T.; KERGUELEN, S. \& LAROUZE, B. Seroprevalence of hepatitis E virus in an adult urban population from Burundi. Amer. J. trop. Med. Hyg., 57: 272-273, 1997.

4. BALAYAN, M.S.; USMANOV, R.K; ZAMYATINA, N.A.; DJUMALIEVA, D.I. \& KARAS, F.R. - Brief report: experimental hepatitis E infection in domestic pigs. J. med. Virol., 32: 58-59, 1990

5. BALDY, J.L.S.- Hepatite por vírus. In: AMATO NETO, V. \& BALDY, J.L.S., ed. Doenças transmissíveis. São Paulo, Sarvier, 1989. p. 467-507.

6. BARZILAI, A.; SCHULMAN, S.; KARETNYI, Y.V. et al. - Hepatitis E virus infection in hemophiliacs. J. med. Virol., 46: 153-156, 1995.
7. BRADLEY, D.W. - Enterically-transmitted non-A, non-B hepatitis. Brit. med. Bull., 46 $442-461,1990$

8. CARRILHO, F.J.; MENDES CLEMENTE, C. \& SILVA, L.C. - Epidemiology of hepatitis A and E infection in Brazil. Gastroent. Hepat., 28: 118-125, 2005.

9. CHANDLER, J.D.; RIDDELL, M.A.; LI, F.; LOVE, R.J. \& ANDERSON, D.A. Serological evidence for swine hepatitis E virus infection in Australian pig herds. Vet. Microbiol., 68: 95-105, 1999.

10. DEAN, A.G.; DEAN, J.Á.; COULOMBIER, D. et al. - Epi info, version 6.04: a word processing database, and statistics program for public health on microcomputers. Atlanta, Centers for Disease Control and Prevention, 1996.

11. DIENSTAG, J.L. - Hepatitis A virus: virologic, clinical, and epidemiologic studies. Human Path., 12: 1097-1106, 1981

12. FOCACCIA, R.; CONCEIÇÃO, O.J.; SETTE Jr., H. et al. - Estimated prevalence of viral hepatitis in the general population of the municipality of São Paulo, measured by a serologic survey of a stratified, randomized and residence-based population. Braz. J. infect. Dis., 2: 269-284, 1998.

13. GONÇALES, N.L.S.; PINHO, J.R.R.; MOREIRA, R.C. et al. - Hepatitis E virus immunoglobulin $\mathrm{G}$ antibodies in different populations in Campinas, Brazil. Clin. diagn. Lab. Immunol., 7: 813-816, 2000.

14. GROEN, P.C. - Hepatitis E in the United States: a case of "hog fever"? Mayo Clin. Proc., 72: 1197-1198, 1997.

15. HAU, C.H.; HIEN, T.T.; TIEN, N.T. et al. - Prevalence of enteric hepatitis A and E viruses in the Mekong River delta region of Vietnam. Amer. J. trop Med. Hyg., 60: 277-280, 1999

16. HSIEH, S.Y.; MENG, X.J.; WU, Y.H. et al. - Identity of a novel swine hepatitis E virus in Taiwan forming a monophyletic group with Taiwan isolates of human hepatitis E virus. J. clin. Microbiol., 37: 3828-3834, 1999.

17. KABRANE-LAZIZI, Y.; FINE, J.B.; ELM, J. et al. - Evidence for widespread infection of wild rats with hepatitis E virus in the United States. J. trop. Med. Hyg., 61: 331335,1999

18. KHUROO, M.S.; RUSTGI, V.K.; DAWSON, G.J. et al. - Spectrum of hepatitis E virus infection in India. J. med. Virol., 43: 281-286, 1994.

19. KRAWCZYNSKI, K. - Hepatitis E. Hepatology, 17: 932-941, 1993.

20. MAST, E.E.; KURAMOTO, I.K.; FAVOROV, M.O. et al. - Prevalence of and risk factors for antibody to hepatitis E virus seroreactivity among blood donors in Northern California. J. infect. Dis., 176: 34-40, 1997

21. MENG, X.J.; HALBUR, P.G.; SHAPIRO, M.S. et al. - Genetic and experimental evidence for cross-species infection by swine hepatitis E virus. J. Virol., 72: 9714-9721, 1998

22. NARAYANAN MENON, K.V. - Non-A to E hepatitis. Curr. Opin. infect. Dis., 15: 529$534,2002$.

23. PANNUTI, C.S.; MENDONÇA, J.S.; CARVALHO, M.J.M.; OSELKA, G.W. \& AMATO NETO, A. - Hepatitis A antibodies in two socioeconomically distinct populations of São Paulo, Brazil. Rev. Inst Med. trop. S. Paulo, 27: 162-164, 1985.

24. PARANA, R.; COTRIM, H.P.; CORTEY-BOENNEC, M.L.; TREPO, C. \& LYRA, L. Prevalence of hepatitis E virus IgG antibodies in patients from a referral unit of liver diseases in Salvador, Bahia, Brazil. Amer. J. trop. Med. Hyg., 57: 60-61, 1997.

25. PAULA, V.S.; ARRUDA, M.E.; VITRAL, C.L. \& GASPAR, A.M.C. - Seroprevalence of viral hepatitis in riverine communities from the western region of the Brazilian Amazon Basin. Mem. Inst. Oswaldo Cruz, 96: 1123-1128, 2001. 


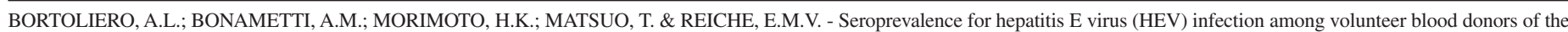
Regional Blood Bank of Londrina, State of Paraná, Brazil. Rev. Inst. Med. trop. S. Paulo, 48(2):87-92, 2006.

26. PURCELL, R.H. \& EMERSON, S.U. - Hepatitis E virus. In: MANDELL, G.L; BENNETT, J.E. \& DOLIN, R., ed. Principles and practice of infectious diseases. Philadelphia, Churchill Livingstone, 2005. p. 2204-2217.

27. SANTOS, D.C.M.; SOUTO, F.J.D.; SANTOS, D.R.L.; VITRAL, C.L. \& GASPAR, A.M. - Seroepidemiological markers of enterically transmitted viral hepatitis A and E in individuals living in a community located in the north area of Rio de Janeiro, RJ, Brazil. Mem. Inst. Oswaldo Cruz, 97: 637-640, 2002.

28. SCHWARTZ, E.; JENKS, N.P.; VAN-DAMME, P. \& GALUN, E. - Hepatitis E virus infection in travelers. Clin. infect. Dis., 29: 1312-1314, 1999.

29. SKIDMORE, S.J. - Factors in spread of hepatitis E. Lancet, 354: 1049-1050, 1999

30. SOUTO, F.J.; FONTES, C.J.; PARANA, R. \& LYRA, L.E. - Short-report: further evidence for hepatitis E in the Brazilian Amazon. Amer. J. trop. Med. Hyg., 57: 149-150, 1997.

31. TRINTA, K.S.; LIBERTO, M.I.M.; PAULA, V.S.; YOSHIDA, C.F. \& GASPAR, A.M. Hepatitis E virus infection in selected Brazilian populations. Mem. Inst. Oswaldo Cruz, 96: 25-29, 2001.
32. TSAREV, S.A.; TSAREVA, T.S.; EMERSON, S.U. \& et al. - ELISA for antibody to hepatitis E (HEV) based on complete open-reading frame-2 protein expressed in insects cells: identification of HEV infection in primates. J. infect. Dis., 168: 369$378,1993$.

33. VITRAL, C.L.; YOSHIDA, C.F.T.; LEMOS, E.R.S.; TEIXEIRA, C.S. \& GASPAR, A.M.C. - Age-specific prevalence of antibodies to hepatitis A in children and adolescents from Rio de Janeiro, Brazil, 1978 and 1995. Relationship of prevalence to environmental factors. Mem. Inst. Oswaldo Cruz, 93: 1-5, 1998.

34. VITRAL, C.L.; PINTO, M.A.; LEWIS-XIMENES, L.L. et al. - Serological evidence of hepatitis E virus infection in different animal species from Southeast of Brazil. Mem. Inst. Oswaldo Cruz, 100: 117-122, 2005.

35. WIBAWA, I.D.; MULJONO, D.H.; MULYANTO, S.I.G. et al. - Prevalence of antibodies to hepatitis E virus among apparently healthy human and pigs in Bali, Indonesia: identification of a pig infected with a gebotype 4 hepatitis E virus. J. med. Virol., 73: $38-44,2004$

36. WU, J.C.; CHEN, C.M.; CHIANG, T.Y. et al. - Clinical and epidemiological implications of swine hepatitis E virus infection. J. med. Virol., 60: 166-171, 2000.

Received: 30 September 2005

Accepted: 14 December 2005 